\title{
Enzyme-linked immunosorbent assay (ELISA) for detection of specific IgA antibodies to mumps virus
}

\author{
BENJAMIN HALEVY, ISRAEL SAROV \\ From the Virology Unit, Soroka University Hospital and Faculty of Health Sciences, Ben Gurion University of \\ the Negev, Beer Sheva, Israel
}

SUMMARY A sensitive enzyme-linked immunosorbent assay (ELISA) is described for detection of $\operatorname{IgA}$ antibodies to mumps virus. Specific mumps $\operatorname{IgA}$ antibodies could be demonstrated in 10 patients with mumps virus infections. No specific mumps IgA antibodies (titres $<1 / 40$ ) were detected by ELISA in 46 control sera (healthy adults; hospitalised patients with various other diseases). The potential application of the ELISA mumps IgA technique in serodiagnosis of mumps infections is discussed.

Mumps is best known as a mild childhood disease, but it can have complications such as orchitis and meningoencephalitis. It is one of the most common causes of viral meningitis. ${ }^{1}$ There are several techniques for the detection of mumps antibodies. These include a neutralisation test (NT), ${ }^{2}$ complement fixation (CF), ${ }^{3}$ haemagglutination inhibition (HI), ${ }^{4}$ single radial immunodiffusion, mixed haemadsorption and haemolysis inhibition. ${ }^{5}$ A highly sensitive radioimmunoassay (RIA) and an enzyme-linked immunosorbent assay (ELISA) for detection of specific mumps IgG antibodies have also been developed recently in a number of laboratories. ${ }^{6-7}$ Ukkonen et al developed an ELISA to detect mumps-specific antibodies. ${ }^{8}$ Friedman recently showed induction of mumps-specific secretory IgA antibodies in saliva by RIA. ${ }^{9}$

In the present study we describe an ELISA for determination of $\operatorname{IgA}$ antibodies to mumps virus in serum. The results obtained for the sera examined were compared with those obtained by CF for the same sera.

\section{Material and methods}

\section{ANTIGEN PREPARATION}

Vero cells were grown in RPMI-1640 culture medium supplemented with $10 \%$ fetal calf serum (FCS), $2 \mathrm{mM}$ L-glutamine, $100 \mathrm{U} / \mathrm{ml}$ penicillin, 200 $\mu \mathrm{g} / \mathrm{ml}$ streptomycin, at $\mathrm{pH} \mathbf{7 \cdot 2}$. The Vero cell cultures were split. One of the resulting sister cultures was infected, and the other was the source of the control antigen. The Jeryl Lynn strain of mumps was

Accepted for publication 16 February 1982 grown in Vero cells in Dulbecco's modified Eagle's medium (DMEM, glucose, $4.5 \mathrm{~g} / \mathrm{l}$, without sodium pyruvate), supplemented with $2 \%$ FCS. The cultures were incubated at $37^{\circ} \mathrm{C}$. Cytopathic effects became apparent two to three days after inoculation with a $1 / 20$ dilution of crude viral lysate.

Cells were washed twice with phosphate-buffered saline (PBS) without $\mathrm{Ca}^{2+}$ and $\mathrm{Mg}^{2+}$, and stored at $-70^{\circ} \mathrm{C}$. They were removed from the glass by repeated freezing and thawing. The infected and control cell suspensions were homogenised by sonication for $1 \mathrm{~min}$ in a Bransonic 12 sonifier. The sonicate was centrifuged at $1400 \mathrm{~g}$ for $10 \mathrm{~min}$ and the supernatant fluid was diluted with PBS to a final protein concentration of $0.2 \mathrm{mg} / \mathrm{ml}$, as determined by the method of Lowry $e t$ al, ${ }^{10}$ to be used as antigen or control antigen. The same mumps antigen preparation was used for both serologic methods (CF and ELISA).

\section{HUMAN SERA}

Seventy-four sera were examined including sera from 30 medical students, eight laboratory workers, eight hospitalised patients with various diseases, and 28 sera of 10 patients with clinically and serologically diagnosed mumps infections, and were stored at $-20^{\circ} \mathrm{C}$ until use. Twentyfold or twofold serial dilutions of sera were prepared in PBS containing $0.05 \%$ Tween 20 (PBST) and tested on both mumps antigen and control antigen.

ELISA

The procedure is a previously described modification $^{11}$ of the ELISA technique described by Bidwell et al. ${ }^{12}$ The assay was carried out on polystyrene, 
U-shaped microtitre plates of Nunc (Microtest 96 $\mathrm{U}-1182)$. Each well received $6 \mu \mathrm{g}$ mumps antigen or control antigen in a volume of $0.03 \mathrm{ml}$. The plates were dried overnight at room temperature and were stored at $-70^{\circ} \mathrm{C}$. Before use, the antigen-coated plates were thoroughly washed with PBST, and this buffer was used for sera and conjugate dilutions as well as for rinsing the plates after each stage of the procedure. Volumes of $0.025 \mathrm{ml}$ human serum dilutions to be tested were dropped into appropriate wells, and the plates were incubated at $37^{\circ} \mathrm{C}$ for $1 \mathrm{~h}$. The plates were rinsed and incubated for $1 \mathrm{~h}$ at $37^{\circ} \mathrm{C}$ with $0.025 \mathrm{ml} /$ well diluted peroxidase-linked rabbit antihuman IgA (specific for $\alpha$ chain) obtained from Dakopatts, Copenhagen. The conjugate was diluted to 1/60 in PBST. After $1 \mathrm{~h}$, the plates were rinsed again, and $0.1 \mathrm{ml}$ of a distilled water solution of $0.08 \%$ 5-amino-salicylic acid with $0.005 \% \mathrm{H}_{2} \mathrm{O}_{2}(\mathrm{pH}$ $6 \cdot 1)$ was added to each well. The enzymatic reaction was stopped by the addition of $0.1 \mathrm{ml} \mathrm{NaOH}(1 \mathrm{~N})$, and the whole reaction mixture was transferred to tubes and diluted with $1 \mathrm{ml} \mathrm{H}_{2} \mathrm{O}$. Absorbance at 450 $\mathrm{nm}$ was measured with a $300 \mathrm{n}$ Gilford Microsample spectrophotometer. Dilutions of sera beginning with $1 / 20$ were tested on both mumps antigen and control antigen.

In each experiment known positive and negative sera were included as well as 10 wells containing no serum dilutions (diluent alone). An average background absorption level was determined from these ten wells.

\section{COMPLEMENT FIXATION (CF)}

The CF assay was carrried out as described by Sever ${ }^{13}$ with 2 units of lyophilised guinea-pig complement (Behringwerke, FRG) and 3 units of hemolysin (Difco, USA).

\section{Results}

The effect of different components of the ELISA system was examined in order to find the optimal conditions for the detection of IgA antibodies to mumps virus.

\section{DETERMINATION OF SERUM TITRE FOR MUMPS \\ IgA B Y ELISA}

Fig. 1 demonstrates the titration curves of a serum positive for $\operatorname{IgA}$ directed against mumps virus with an ELISA titre of $1 / 640$, and a mumps IgA-negative serum. The serum titre was defined as the intersection between the titration curve using viral antigen and the corresponding curve obtained with the control antigen, as previously described. ${ }^{14}$ The negative sera had control antigen curves either identical to,

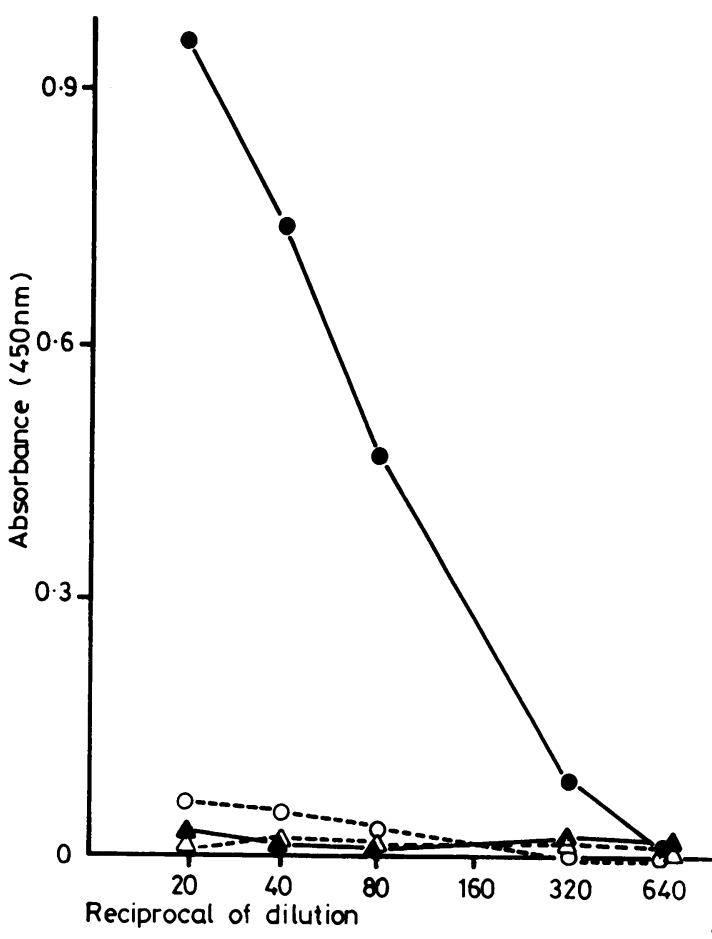

Fig. 1 Positive and negative mumps specific IgA sera as determined by ELISA. Titration curves of a serum positive for mumps-specific IgA $(\bigcirc)$ and a negative serum $(\Delta)$. Solid lines, solid symbols: serum tested on mumps antigen. Dashed lines, open symbols; serum tested on control Vero antigen. ELISA mumps IgA titre determined for the positive sera was 640. The absorbance at $450 \mathrm{~nm}$ given in the figure represents the optical density of the undiluted samples.

insignificantly lower than, or slightly higher than viral antigen curves.

CONJUGATE AND ANTIGEN CONCENTRATIONS A known positive and a known negative serum were tested on different concentrations of mumps antigen and of control antigen. No significant change in the titre of the positive serum was observed when the concentration of the mumps antigen used was in the range of $200-300 \mu \mathrm{g} / \mathrm{ml}$, whereas with $50-100$ $\mu \mathrm{g} / \mathrm{ml}$, serum titres were lower. When the negative serum was checked, it was negative with all concentrations of mumps antigen/control antigen examined. A concentration of $200 \mu \mathrm{g} / \mathrm{ml}$ mumps and control antigen was chosen for use in further experiments.

A dilution of $1 / 60$ of the peroxidase-conjugated rabbit antihuman $\operatorname{IgA}$ was chosen for standard use. Under these conditions, $20 \mathrm{~min}$ were necessary to obtain the maximal colour reaction with 5-aminosalicylic acid. 
Mumps antibody titres measured in sera by specific IgA-ELISA and CF at acute and convalescent stages

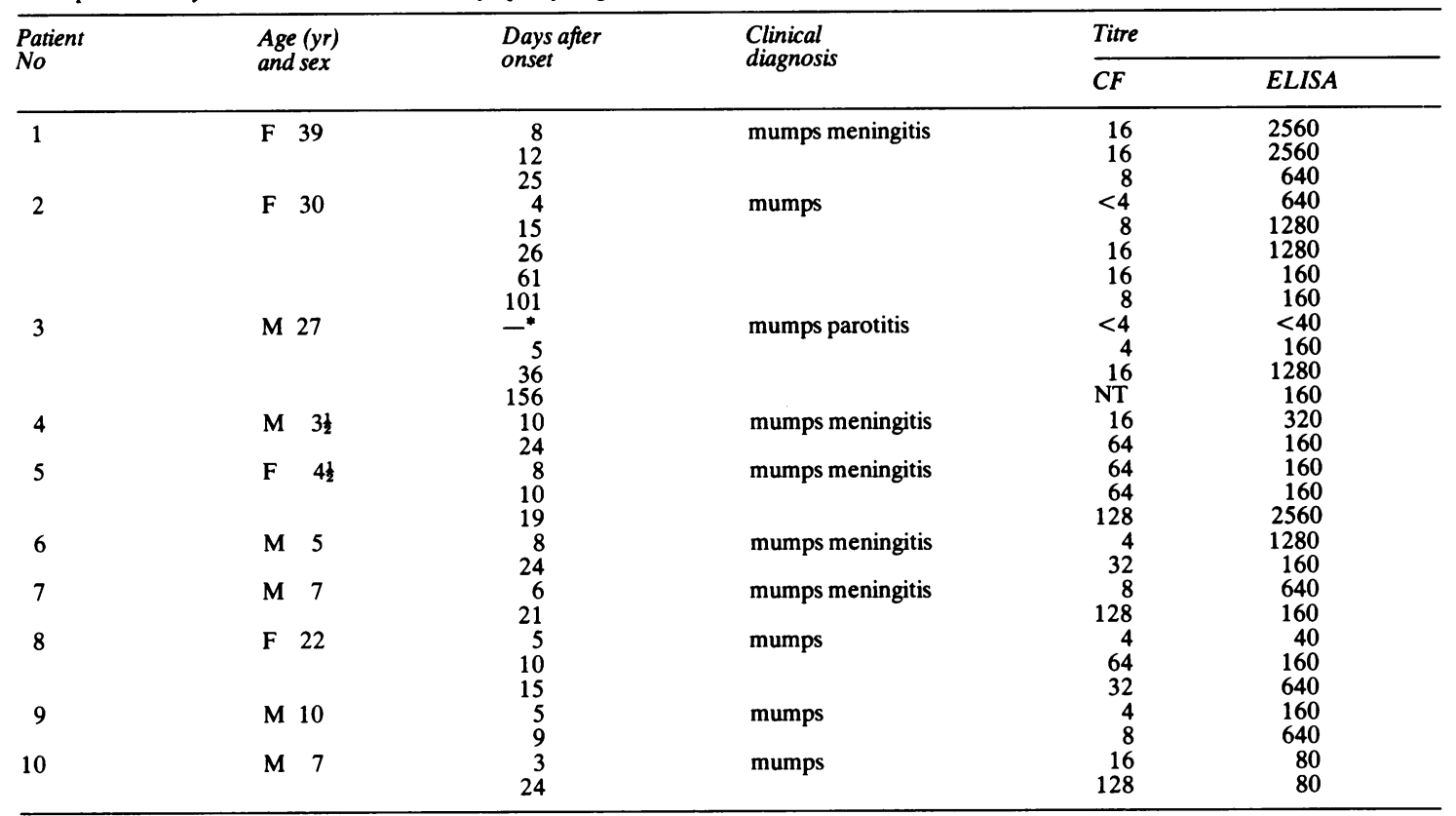

* = two years before onset

NT $=$ not tested.

\section{REPRODUCIBILITY}

We examined the reproducibility of the technique by testing one positive serum in 25 different experiments. The titre was reproducible within a twofold range.

\section{MUMPS PATIENTS}

Twenty eight sera from 10 mumps patients were tested for mumps virus antibodies by CF and by the ELISA techniques (Table). For all the patients mumps-specific IgA was detected by ELISA in all serum samples available. In one of the patients (case 3 ), a single serum sample taken two years before onset of mumps parotitis showed no mumps specific IgA antibodies (titre <1/40). A marked decrease of mumps IgA titre was already seen after about 20-25 days in four of the mumps patients. In serum samples of cases 2 and 3 mumps $\operatorname{IgA}$ antibodies were still observed (titre 1/160), 101 and 150 days respectively after onset of illness.

\section{CONTROL ADULTS}

Forty-six sera of blood donors (see "Human sera" under "Material and methods") were evaluated for mumps-specific IgA antibodies by ELISA and by CF. In all sera no mumps $\operatorname{IgA}$ antibodies (titre $<1 / 40$ ) were observed by ELISA. Five of these sera were negative for mumps antibodies by the CF test (titre
$<1 / 4$ ) while the others were positive (titres $1 / 4$ to $1 / 16)$. The possibility that mumps $\operatorname{IgA}$ antibodies might be detected at titres lower than 1/40 in control sera needs to be examined.

\section{Discussion}

In the present study we have developed an enzymelinked immunosorbent assay (ELISA) for detection of $\operatorname{IgA}$ antibodies to mumps virus. In our examinations we found high titres of $\operatorname{IgA}$ antibodies specific for mumps in the sera of 10 mumps patients studied. Detection of high IgA titres in mumps patients by the ELISA technique described indicates that the method has potential for serodiagnosis of mumps infections since no mumps IgA antibodies (titre $<1 / 40$ by ELISA) were found in 46 control sera of healthy adults and patients hospitalised with various other diseases. In one serum sample available three days after onset of illness, IgA antibodies were already observed (titre 1/80) by ELISA. However, before one accepts this mumps IgA ELISA technique as a standard technique for serodiagnosis of mumps infections, (i) the possible cross creactivity with other parainfluenza viruses needs to be examined since there is a report of one patient out of 12 with parainfluenza virus 3 infection (as determined by a rise in CF titre) having a rise in IgG titre 
to mumps when tested by ELISA; (ii) the persistence of the specific IgA antibodies needs to be carefully examined in larger population samples. We found that in two patients IgA titres seemed to decline after about one month, but were still positive about four to six months after onset of illness. Studies which have been carried out with respect to persistence of $\operatorname{IgA}$ antibodies after other viral infections have not yielded uniform results. In patients with Epstein-Barr virus (EBV) mononucleosis and influenza, IgA antibodies appeared in the early stages of disease and were not detected 10 weeks after onset. ${ }^{15}{ }^{16}$ Conversely, Halonen et $a{ }^{17}{ }^{17}$ by a highly sensitive radioimmunoassay (RIA) have shown that IgA antibodies to rubella viruses persist in most rubella patients for at least several months. The longest persistence time of $\operatorname{IgA}$ recorded is over four years. ${ }^{18}$ Recently, it became evident that also IgM antibodies induced during various viral infections persist longer than was previously thought when sera were examined by less sensitive techniques. ${ }^{10-22}$ It seems that the persistence of $\operatorname{IgA}$ antibodies depends upon the virus involved, individual variations among the patients, and most importantly, on the sensitivity of the method used to detect specific IgA.

Recent investigations indicate that serum $\operatorname{IgA}$ antibody is involved in the transport of a foreign antigen from the circulation into the bile. ${ }^{23-27}$ Very little is known about the role of serum IgA antibodies in viral infections. Of particular interest is the finding of Henle and Henle that nearly all nasopharyngeal carcinoma patients tested prior to specific therapy had IgA antibodies to EBV viral capsid antigen (VCA). ${ }^{28}$ HSV-2 IgA antibodies to membrane antigen were found to be detected significantly more frequently and at higher titres in patients with cervical dysplasia and neoplasia than among matched controls. ${ }^{29}$

Specific IgA antibodies can be detected in both primary and recurrent varicella zoster virus (VZV) and cytomegalovirus (CMV) infections by the ELISA technique. ${ }^{113031}$ There have been suggestions that mumps virus may be associated with neurological, autoimmune and malignant diseases $^{32-37}$ Examination of sera of persons with such disorders for the presence of IgA antibodies to mumps virus is warranted. The technique described herein may be useful for such studies as well as for routine diagnostic serology.

This work was supported in part by the Gulton Foundation Inc, USA. We would like to thank Dr M Friedman, Ms E Levy, Ms V Goldstein, Ms N Kimmel and all the members of the Virology Unit for their excellent technical assistance.
The secretarial assistance of Ms S Oren is gratefully appreciated.

\section{References}

${ }^{1}$ Thieffry S. The aseptic meningitis. In: Debie R, Celers S, eds. Clinical virology. Philadelphia: WB Saunders, 1970:208.

${ }^{2}$ Deinhart FW, Shramek GJ. Development of an attenuated mumps virus vaccine. 1. Determination of neutralising serum antibodies against mumps virus. J Immunol 1964;93:462-5.

${ }^{3}$ Henle G, Harris S, Henle W. The reactivity of various human sera with mumps complement fixation antigens. $J$ Exp Med 1948;88:133.

- Deinhart FW, Shramek GJ. Mumps virus. In: Lennette EH, Spaulding EH, Truant JP, eds. Manual of clinical microbiology 2nd ed. Washington DC: American Society for Microbiology, 1974:703.

${ }^{5}$ Norrby E, Grandien M, Orvell C. New tests for characterication of mumps virus antibodies: hemolysis inhibition, single radial immunodiffusion with immobilised virions and mixed hemadsorption. J Clin Microbiol 1977;5:346.

- Daugharty H, Warfield DT, Hemingway WD, Casey HL. Mumps class-specific immunoglobulins in radioimmunoassay and conventional serology. Infect Immun 1973;7:380-5.

${ }^{7}$ Engel S, Goldstein V, Sarov I. Enzyme-linked immunosorbent assay for detection of antibodies to mumps virus. Isr J Med Sci 1980;16:461-4.

- Ukkonen P, Vaisanen O, Penttinen K. Enzyme linked immunosorbent assay for mumps and parainfluenza type 1 immunoglobulin $\mathrm{G}$ and immunoglobulin $\mathbf{M}$ antibodies. J Clin Microbiol 1980;11:319-23.

- Friedman MG. Salivary IgA antibodies to mumps virus during and after mumps. $J$ Infect Dis 1981;143:617.

${ }^{10}$ Lowry OH, Rosebrough NJ, Farr AL, Randall RJ. Protein measurement with the Folin phenol reagent. J Biol Chem 1951;193:265-75.

${ }^{11}$ Levy E, Sarov I. Determination of IgA antibodies to human cytomegalovirus by enzyme linked immunosorbent assay (ELISA). $J$ Med Virol 1980;6:249-57.

12 Bidwell DE, Bartlett A, Voller A. Enzyme immunoassay for viral diseases. $J$ Infect Dis 1977;135:274-8.

${ }^{18}$ Sever JL. Application of a microtechnique to viral serological investigations. J Immunol 1962;88:320-9.

${ }^{14}$ Sarov I, Andersen P, Andersen HK. Enzyme linked immunosorbent assay (ELISA) for determination of IgG antibodies to human cytomegalovirus. Acta Pathol Microbiol Scand [B] 1980;88:1-9.

${ }^{15}$ Brown GC, O'Leary TP. Fluorescent antibodies to influenza virus in various immunoglobulin fractions of serum after natural infection or vaccination. J Immunol 1973;110:889-96.

${ }^{16}$ Nikoskelainen J, Neel EU, Stevens DA. Epstein-Barr virus specific serum immunoglobulin $A$ as an acute phase antibody in infectious mononucleosis. J Clin Microbiol 1979;10:75-9.

${ }^{17}$ Halonen P, Meurman O, Matikainen MT, Torfason E, Bennick H. IgA antibody response in acute rubella determined by solidphase radioimmunoassay. J Hyg (Camb) 1979;83:69-75.

${ }^{18}$ Hornsleth A, Leerhoy J, Grauballe P, Spanggaard H. Persistence of rubella virus specific immunoglobulin $\mathbf{M}$ and immunoglobulin $A$ antibodies: Investigation of successive serum samples with lowered immunoglobulin $G$ concentration. Infect Immun 1975;11:804-8.

19 Edelman R, Schneider RJ, Vajjajiva A, Pornpibul R, Voodlikul P. Persistence of virus specific IgM and clinical recovery after Japanese encephalitis. Am J Trop Med 1976;25:733-8.

${ }^{20}$ Monath TPC. Neutralizing antibody responses in the major immunoglobulin classes to yellow fever 17D vaccination of humans. Am J Epidemiol 1971;93:122-9. 
${ }^{21}$ Scott RM, McGown JM, Russell PK. Human immunoglobulin specificity after group B arbovirus infections. Infect Immun 1972;6:277-81.

22 Stallman ND, Allan BC, Sutherland CJ. Prolonged rubella IgM antibody response. Med J Aust 1974;2:629-31.

${ }^{23}$ Fisher MM, Nagy B, Bazin H, Underdown BJ. Biliary transport of IgA: role of secretory component. Proc Natl Acad Sci USA 1979;76:2008.

24 Orlans E, Peppard J, Fry JF, Hinton RH, Mullock BM. Secretory component as the receptor for polymeric IgA on rat hepatocytes. J Exp Med 1979;150:1577-81.

${ }^{25}$ Socken DJ, Jeejeebhoy KN, Bazin U, Underdown BJ. Identification of secretory component as an IgA receptor on rat hepatocytes. J Exp Med 1979;150:1538-48.

${ }^{26}$ Stokes CR, Swarbrick ET, Soothill JF. Immune elimination and enhanced antibody responses: functions of circulating IgA. Immunology 1980;40:455.

${ }^{27}$ Russel MW, Brown TA, Mestecky J. Role of serum IgA: hepatobiliary transport of circulating antigen. J Exp Med 1981;153:968-76

${ }^{28}$ Henle G, Henle W. Epstein-Barr virus specific IgA serum antibodies as an outstanding feature of nasopharyngeal carcinoma. Int J Cancer 1976;17:1-7.

${ }^{20}$ Mendis LN, Best JM, Banatvala JE. Class specific antibodies (IgG and IgA) to membrane antigens of herpes simplex type-2 infected cells in patients with cervical dysplasia and neoplasia. Int J Cancer 1981;27:669-77.

${ }^{30}$ Levy E, Sarov I. Detection of specific IgA antibodies in serum of patients with varicella and zoster infections. Intervirology 1981;15:103-10.

${ }^{31}$ Sarov I, Siqueira-Linhares M, Chardonnet $Y$ et al. Detection of specific IgA antibodies in serum of kidney transplant patients with recurrent cytomegalovirus infections. Intervirology 1981;15:228-34.

s2 Kenneth PJ, Wolinsky S, Ginsberg AH. Immune mediated syndromes of the nervous system related to virus infections. In: Vinken PS, Bruyn GW, eds: Handbook of clinical neurologyinfections of the nervous system Part II Amsterdam, New York, Oxford: North Holland Publishing Co, 1978:400.

ss Leneman F. The Guillain-Barré syndrome. Definition, etiology and review of 1100 cases. Arch Intern Med 1966;118:139-44.

34 Naficy K, Nategh R, Ghadimi H. Mumps pancreatitis without parotitis. Br Med J 1973;i:529.

as Prince GA, Jenson AB, Billups LC, Notkins AL. Infection of human pancreatic beta cell cultures with mumps virus. Nature 1978;271:158-61.

36 Sultz HA, Hart BA, Zielezny M. Is mumps virus an etiologic factor in juvenile diabetes mellitus? J Pediatr 1975;86:654-6.

${ }^{37}$ Vuori M, Lahikainen EA, Peltonen T. Perceptive deafness in connection with mumps: A study of 298 service men suffering from mumps. Acta Otolaryngol 1962;55:231-6.

Requests for reprints to: Dr Israel Sarov, Virology Unit, Faculty of Health Sciences, Ben Gurion University of the Negev, Beer Sheva, Israel. 